\title{
Disinfecting Poultry Slaughterhouse Wastewater Using Copper Electrodes in the Electrocoagulation Process
}

\author{
Amin Zarei ${ }^{1}$, Hamed Biglari ${ }^{2 *}$, Mohsen Mobini ${ }^{3}$, Abdollah Dargahi $^{4}$, \\ Gholamreza Ebrahimzadeh ${ }^{5}$, Mohammad Reza Narooie ${ }^{6}$, Ehsan Abouee Mehrizi ${ }^{7}$, \\ Ahmad Reza Yari ${ }^{8}$, Mohammad Javad Mohammadi', Mohammad Mehdi Baneshi ${ }^{10}$, \\ Rasoul Khosravi" ${ }^{11}$ Mohsen Poursadeghiyan ${ }^{12}$
}

${ }^{1}$ Department of Environmental Health Engineering, School of Health, Torbat Heydariyeh University of Medical Sciences, Torbat Heydariyeh, Iran

${ }^{2}$ Department of Environmental Health Engineering, School of Public Health, Gonabad University of Medical Sciences, Gonabad, Iran

${ }^{3}$ Department of Environmental Health Engineering, School of Health, Rafsanjan University of Medical Sciences, Rafsanjan, Iran

${ }^{4}$ Department of Environmental Health Engineering, School of Public Health, Kermanshah University of Medical Sciences, Kermanshah, Iran

${ }^{5}$ Department of Environmental Health Engineering, School of Public Health, Zabol University of Medical Sciences, Zabol, Iran

${ }^{6}$ Department of Environmental Health Engineering, School of Public Health, Iranshahr University of Medical Sciences, Iranshahr, Iran

${ }^{7}$ Department of Environmental Health Engineering, Faculty of Public Health, North Khorasan University of Medical sciences, Bojnurd, Iran

${ }^{8}$ Research Center for Environmental Pollutants, Qom University of Medical Sciences, Qom, Iran

${ }^{9}$ Student Research Committee, Department of Environmental Health Engineering, School of Public Health and Environmental Technologies Research Center, Ahvaz Jundishapur University of Medical Sciences, Ahvaz, Iran

${ }^{10}$ Social Determinants of Health Research Center, Yasuj University of Medical Sciences, Yasuj, Iran

${ }^{11}$ Social Determinants of Health Research Center, Birjand University of Medical Sciences, Birjand, Iran

${ }^{12}$ Research Center in Emergency and Disaster Health, University of Social Welfare and Rehabilitation Sciences, Tehran, Iran 


\begin{abstract}
Insufficiencies and deficiencies in slaughterhouses could adversely affect public health. Wastewater from slaughtering, along with high microbial pollution, results in serious pollution to the surrounding environment if not treated. This study sought to investigate the efficiency of the electrocoagulation process using copper electrodes in the disinfection of poultry slaughterhouse wastewater without any initial controlling. The physical and chemical properties of samples of wastewater taken from a poultry slaughterhouse were first analyzed. Then the samples were subjected to the electrocoagulation process using copper electrodes in potential differences of 10,20 , and $30 \mathrm{~V}$ over a period of $60 \mathrm{~min}$. Then the removal efficiency of total coliforms was examined in accordance with standard methods found in textbooks. The results obtained from this study indicated that the efficiency of the electrocoagulation process increased by an increase in process time as well as in electric potential difference. The maximum removal efficiency of total coliforms was $100 \%$ in potential difference, equal to $30 \mathrm{~V}$ in the reaction time of $10 \mathrm{~min}$. Moreover, the results of this study revealed that the electrocoagulation process using a copper electrode was fully able to remove total coliform from poultry slaughterhouse wastewater.
\end{abstract}

Keywords: electrocoagulation, disinfection, total coliform, wastewater, slaughterhouse, copper electrodes

\section{Introduction}

Along with the growth of human society and its needs as well as an increase in rising demand for food and the development of manufacturing industries, pollutants that can bring about short-term and/or long-term problems for humans have been entering the environment [13]. Among the above-mentioned industries, the animal protein production industry in the slaughterhouse stage and their creation of a clear risk through discharging their produced wastewater on the environment can be pointed out [4-5]. Poultry slaughterhouses are one of the most important centers for meeting proteins such as meat required for humans [6]. Insufficiencies and deficiencies in slaughterhouses may lower the level of public health. If wastewater resulting from slaughtering associated with high pollution is not treated, it causes serious pollution in the environment [7]. In various stages of slaughtering, large amounts of wastewater containing blood, rumen contents, and materials from washing (equipment and hall) is produced and causes serious pollution of surface water, groundwater, and agricultural lands via discharge into the environment [8]. In addition to slaughterhouse wastewater, several thousand tons of slaughterhouse waste such as bones, offal, etc. are produced by non-industrial slaughterhouses and released around slaughterhouses, which is one of the most important factors for environmental pollutants [9]. On the use of wastewater, microbial guidelines of the United States Environmental Protection Agency (EPA) has determined about 200 and 0 colonies per 100 $\mathrm{mL}$ of treated wastewater for restricted and unrestricted urban use, respectively $[3,10]$. Also, according to wastewater discharge standards in Iran, the number of fecal coliforms and total coliforms of MPN should be reduced 400 and 1,000 per $100 \mathrm{~mL}$, respectively, in wastewater, and output wastewater should not have an unpleasant smell and floors and floaters [11]. Due to the high amount of organics in wastewaters, in the case of discharging it in receiving water, oxygen dissolved in the water reduces and reaches zero. These conditions will lead to consequences such as loss of aquatic organisms and creating an unpleasant smell in the receiving waters [12-13].

Pathogenic microorganisms can be pathogenic to humans by discharging slaughterhouse wastewater [14]. Bacteria such as Salmonella, Shigella, and Brucella are likely to be present in slaughterhouse wastewater. Although coliform bacteria in the digestive tract of livestock and poultry are harmless, their presence in water contaminates it and causes the possible presence of other pathogens [15]. The release of contaminants is possible to a very large radius of wastewater discharge [16]. Today's conventional wastewater treatment methods include a variety of physical, biological, and chemical processes such as ion exchange, reverse osmosis [12, 17], biological denitrification [18], adsorption [19-21], and chemical reduction [22-23].

One of the methods in high-pollutant wastewater disinfiction is the electrocoagulation process ( $\mathrm{EC}([7,24]$. EC is an electrochemical process using direct current (DC) to remove contaminants from the solution. In the EC process, coagulant is made up of good materials through electrolytic oxidation of an anode. Then, charged ionic species, heavy metals, or cases other than this are removed through providing ability to react with an ion with opposite electrical charge or metal hydroxides produced in wastewater [9]. In the electrocoagulation process, it is possible to use a different type of electrode. Today some research has noted disinfection capability usage of some electrodes such as copper, which has a microbial property and so far more than 350 copper 
alloys are registered with the EPA as solid antimicrobial materials [25]. Considering that copper alloy can kill bacteria continuously without any chemical additives and has no harmful effect on operators in non-digestive contact and low concentrations of it [26], and also due to the extent and frequency of livestock and poultry slaughterhouses, this study was aimed at disinfecting poultry slaughterhouses using the electrocoagulation process with a copper electrode to preserve water resources and realize treatment standards.

\section{Materials and Methods}

All chemicals used in this descriptive-analytic study were prepared and used from the Merck Company in Germany (Grade A). Wastewater samples were collected from a depth of $30 \mathrm{~cm}$ of output wastewater from the storage tank of a poultry slaughterhouse in Ghaen, Iran, after homogenizing the wastewater at the end of the daily work shift. The samples were kept at a temperature of $4^{\circ} \mathrm{C}$ and transported to the laboratory in less than one hour. Then the physical and chemical properties of the samples were analyzed [27]. For doing the electrocoagulation process, they were non-continuously transferred into a cubic rectangular made up of an unbreakable glass and resistant to acid corrosion (buccal) with dimensions of $12 \times 12 \times 16 \mathrm{~cm}$ (length $\times$ width $\times$ depth $)$ and an effective volume of $2 \mathrm{~L}$ equipped with 6 electrodes made of iron and copper ( $75 \%$ purity) within just a connection to a transformer for converting urban electric alternating current (AC) to direct DC. The electrodes were connected to the current by a bipolar method, and the other electrodes were inductively applied. In the following, the process efficiency in the removal of coliform from wastewater was examined at different voltages from 10 to $40 \mathrm{~V}$ at normal $\mathrm{pH}$ and $\mathrm{EC}$ and a constant of slaughterhouse wastewater over $60 \mathrm{~min}$. Grid electrodes (for the better flow of wastewater between two sides of electrodes for the better coagulation of wastewater) with a thickness of $2 \mathrm{~mm}$ and area of 280 square centimeters (area of grid electrodes) were used together after making the grid according to the number of holes and their diameter (calculated using caliper and fixed distance of $2 \mathrm{~cm}$ ). Sampling of wastewater was performed once every $15 \mathrm{~min}$ through power outage using a damp cotton swab. The samples were plated and counted in TSA and blood agar cultures using the pour plate method. All tests were repeated three times. Finally, the data were analyzed using descriptive statistics parameters and Microsoft Excel software.

\section{Results and Discussion}

In recent years, the use of advanced oxidation processes has been an effective alternative for chemical and physical methods of wastewater treatment and the electrocoagulation process is one of them [14].
The physical and chemical properties of poultry slaughterhouse wastewater in Ghaen, Iran were $\mathrm{pH}$ $7.95 \pm 0.5$, electrical conductivity $49.87 \pm 8.2 \mathrm{mS} / \mathrm{cm}$, COD $3810.48 \pm 15.44 \mathrm{mg} / \mathrm{L}, \mathrm{BOD}_{5} 1966.13 \pm 67.30 \mathrm{mg} / \mathrm{L}$, TKN 203.7 $\pm 98.94 \mathrm{mg} / \mathrm{L}, \quad \mathrm{TSS} 946.45 \pm 66.09 \mathrm{mg} / \mathrm{L}$, phosphorous $46.1 \pm 29.61 \mathrm{mg} / \mathrm{L}$, total coliform $110,000 \pm$ $0.00 \mathrm{CFU} / 100 \mathrm{~mL}$, and temperature $26.2 \pm 3.88^{\circ} \mathrm{C}$.

Temperature changes: Fig. 1a) shows the mean temperature changes of water environment within electrocoagulation process. Fig. 1a) indicates that the temperature of water environment has increased about $7^{\circ}$ under the electrocoagulation process after it had the same temperature with the laboratory environment and reached a maximum temperature of $34^{\circ}$. Many studies have reported similar results [28-29]. It seems that enhancing the temperature is one of the bacterial elimination factors. The reaction temperature affects the physical and chemical properties of the solute, such as viscosity and vapor pressure. This viscosity reduction enhances the process efficiency due to the pole potential difference [30].

pHs changes: Fig. 1b) shows the mean $\mathrm{pH}$ changes during the electrocoagulation process in a reaction time of $60 \mathrm{~min}$. Fig. 1b) indicates that $\mathrm{pH}$ has increased about three units during the electrocoagulation process and reached from 5.7 to 8.45 at the onset of the process after $60 \mathrm{~min}$. The coagulation process is largely dependent on $\mathrm{pH}$ [31], which can potentially be effective in the sequestration of coagulants and the size of coagulant particles [29, 32]. The coagulation process can be a competitor between hydrogen ions and products from metal electrolysis in reaction to organic matter in low $\mathrm{pH}$ and a competitor between hydroxide ions and organic anions in reaction with metal ions in higher $\mathrm{pH}$ values and prevent the optimal efficiency of the process [29]. $\mathrm{pH}$ increase during the electrocoagulation process is due to the production of $\mathrm{OH}^{-}$ions at the cathode reactions [9]. The increase of $\mathrm{pH}$ of the process environment improves the performance of electrocoagulation process and increases the removal of pollutants because the efficiency of the iron coagulant acts better in neutral and slightly alkaline environments, especially for $\mathrm{pH}$ in the range of 6 to 9 [14]. Also, given the pourbaix diagram (E-pH) for copper, in the process of electric dissolution, $\mathrm{Cu}^{2+}$ ions are soluble only at $\mathrm{pH}$ less than 7 and with increasing the concentration of $\mathrm{Cu}^{2+}$ ions, an area of $\mathrm{pH}$ in which the ion is soluble becomes narrow. At $\mathrm{pH}$ above $7, \mathrm{CU}^{2+}$ is insoluble and $\mathrm{CUO}_{(\mathrm{s})}$ is obtained from the dehydration of $\mathrm{Cu}(\mathrm{OH})_{2(\mathrm{~s})}[29]$.

\section{Effects of Time and Potential Changes}

Fig. 1c) shows the efficiency of the electrocoagulation process for the removal of total coliform bacteria from poultry slaughterhouse wastewater in reaction times and different potential differences. Fig. 1c) indicates that in the electrocoagulation process using copper electrodes, by increasing reaction time and electric potential difference, the removal efficiency of total coliforms has increased. 

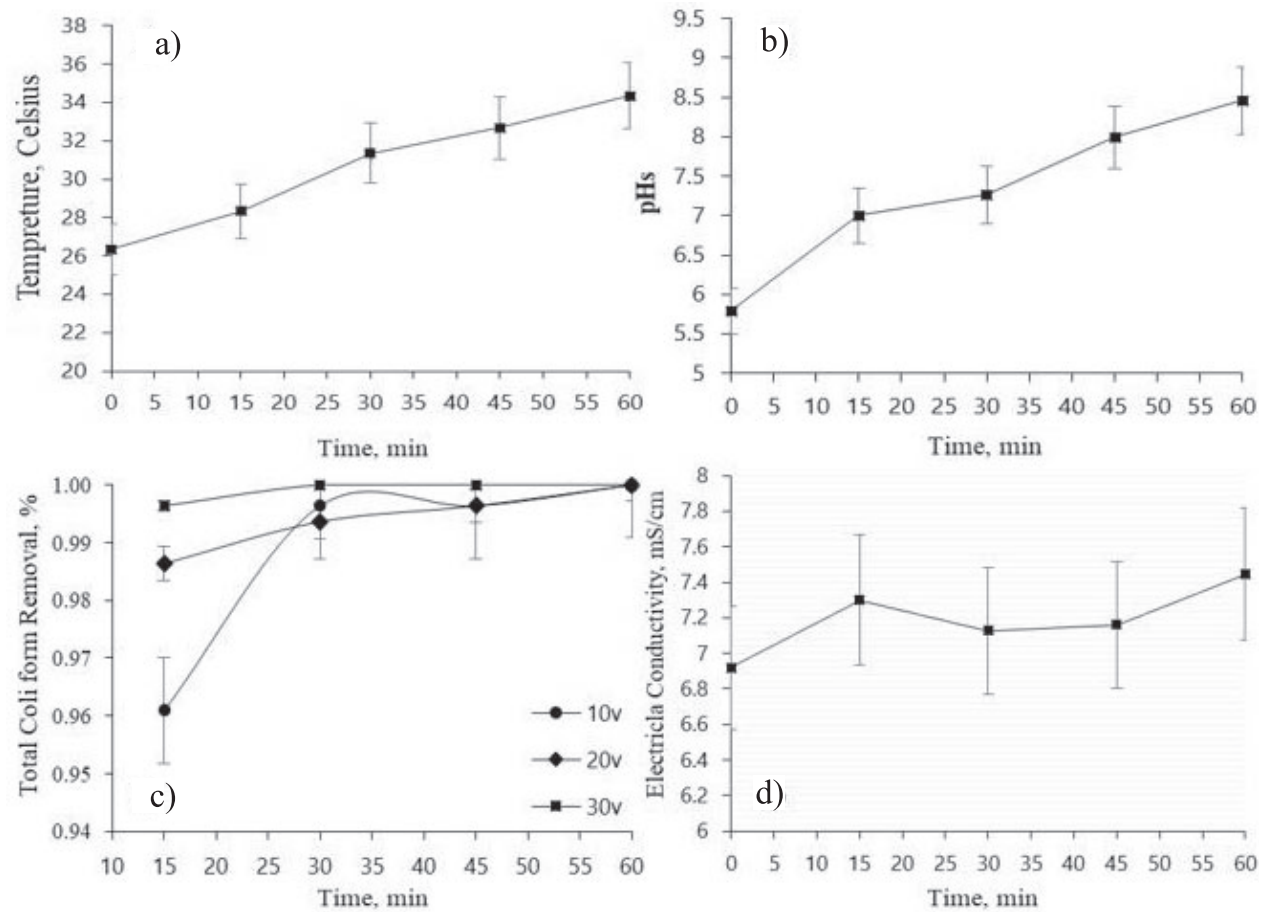

Fig. 1. Disinfection at different times and potential c), temperature changes a), $\mathrm{pH}$ changes b), and electrical conductivity changes d).

The maximum removal efficiency of total coliforms has been obtained equal to $100 \%$ in the potential difference equal to $30 \mathrm{~V}$ and at $60 \mathrm{~min}$ response duration. Three major processes including forming coagulants in the aqueous phase, absorbing soluble or colloidal pollutants on the coagulants, and removing bacteria by settling or flotation in the electrocoagulation process are the main causes of disinfecting wastewater samples during the electrolytic reaction at the electrodes [28]. In addition, the efficiency of the process depends on the amount of free copper ions produced in the solution as well [33]. In this study at optimum condition $0.29 \mathrm{~kW} / \mathrm{h}$ and 1.81 and $0.79 \mathrm{Kg}$ iron and copper per cubic meter wastewater were consumed, respectively. On the other hand, since the amount of produced copper ions is associated with reaction time, by increasing reaction time, the production of coagulants is enhanced and removal efficiency has been improved [29]. According to Faraday's law, it has also been reported that the mount of passing charge from solution is directly related to producing the amount of dissolved iron [32]. Electric potential difference not only determines the amount of coagulant generated in the solution, but also enhances the treatment efficiency in the electrocoagulation process through facilitating the production of bubbles and improving the size and growth of coagulant 'flocks' [31, 34]. In addition, some studies have reported that by increasing current, the size of the bubbles is reduced which leads to quicker and more removal of pollutants.

Increasing the voltage enhances shear force on the electrode surface and the production of coagulant and disinfectant (copper solution) in electrochemical processes [35]. In a study by Rahmani et al. [35], similar results on the effect of voltage variations on the removal of coliforms in drinking water have been reported. In some other studies, it has also been reported that during an electrochemical process, $\mathrm{OH}^{-}$and $\mathrm{Cl}^{-}$ions and other products are factors for wastewater disinfection [36]. In their study, Massoudinejad et al. reported that by increasing the electrolysis time of water for $30 \mathrm{~min}$, the removal efficiency of bacteria increased by about $5 \%$ [37]. In the study entitled the removal of material from industrial wastewater using the electrocoagulation process equipped with a copper electrode, Barrera-Díaz et al. reported that using a copper electrode is highly efficient in removing organic matter and that copper has been completely disinfected at a concentration of $4 \mathrm{ppm}$ [29]. It seems that according to the antimicrobial properties of copper, using its electrode in the electrolysis process improves the efficiency of the process for certain removal of bacteria in the coliform group from wastewater.

\section{Electrical Conductivity Changes}

Fig. 1d) shows electrical conductivity changes in the environment under the electrocoagulation process over $60 \mathrm{~min}$., and indicates that electrical conductivity has increased by about $0.5 \mathrm{~ms} / \mathrm{cm}$. Some studies have reported that by increasing the concentration of electrolyte in electrocoagulation process, the removal efficiency of contaminant becomes more as well because of the direct effect of electrolyte concentration on the electrical conductivity of the solution $[33,37]$. In constant current, with increasing the concentration of electrolyte the voltage decreases. By increasing the electrical 
conductivity of the solution, anodic dissolution increases and results in an increase in the rate of coagulant in the solution [34].

\section{Conclusions}

In this study, the poultry slaughterhouse wastewater disinfection process was evaluated using the electrocoagulation process equipped with the copper electrodes. The results indicated that by increasing the reaction time and electric potential difference, total coliform bacteria removal efficiency has increased in the way that after $60 \mathrm{~min}$, at the potential difference of 10 volts and after 30 minutes at the potential difference of 30 volts, the bacteria in the wastewater were completely destroyed and had no regrowth. Also, at optimum conditions $0.29 \mathrm{~kW} / \mathrm{h}$ and 1.81 and $0.79 \mathrm{~kg}$ iron and copper per cubic meter wastewater were consumed, respectively. Meanwhile, the $\mathrm{pH}$ of the wastewater, which was acidic at first, improved to the neutral range and made the discharge of wastewater quite desirable in terms of $\mathrm{pH}$ standard after $30 \mathrm{~min}$.

\section{Acknowledgements}

We would like to thank and appreciate Yasuj University of Medical Sciences for funding and all colleagues who have collaborated on writing this paper.

\section{Ethical Clearance}

Taken from the ethical committee of Yasuj University of Medical Science with grant numbers of $92 / 75$ by the Student Research Committee.

\section{References}

1. BIGLARI H., SAEIDI M., NAROOIE M.R., ALIPOUR V., SOHRABI Y., KHAKSEFIDI R., RAHDAR S., ZAREI A., AHAMADABADI M. Survey on the quantity of hazardous wastes generated in Isfahan medical centers,Iran. ., Int. J. Pharm. Technol. 8, 17872, 2016.

2. BIGLARI H., ZAREI A., SOHRABI Y., CHARGANEH S.S., DABIRIAN M., JAVAN N. An analysis of Kashan municipal solid waste, Iran. Res. J. Appl. Sci. 11, 554, 2016.

3. ALIPOUR V., REZAEI L., ETESAMIRAD M.R., RAHDAR S., NAROOIE M.R., SALIMI A., HASANI J., KHAKSEFIDI R., SADAT S.A., BIGLARI H. Feasibility and applicability of solar disinfection (SODIS) for point-ofuse water treatment in Bandar Abbas, South of Iran. J. Glob. Pharma Technol. 9, 40, 2017.

4. BAYAR S., YILDIZ Y., YILMAZ A., KOPARAL A.S. The effect of initial $\mathrm{pH}$ on treatment of poultry slaughterhouse wastewater by electrocoagulation method. Desalin. Water Treat. 52, 3047, 2014.

5. AHAMADABADI M., SAEIDI M., RAHDAR S., NAROOIE M.R., SALIMI A., ALIPOUR V., KHAKSEFIDI
R., BANESHI M.M., BIGLARI H. Assessment of the chemical quality of groundwater resources in Chabahaar City using GIS software in 2016. Res. J. Appl. Sci. 11, 1399, 2016.

6. OZYONAR F., KARAGOZOGLU B. Investigation of technical and economic analysis of electrocoagulation process for the treatment of great and small cattle slaughterhouse wastewater. Desalin. Water Treat. 52, 74, 2014.

7. ORSSATTO F., FERREIRA TAVARES M.H., MANENTE DA SILVA F., EYNG E., FARIAS BIASSI B., FLECK L. Optimization of the pretreatment of wastewater from a slaughterhouse and packing plant through electrocoagulation in a batch reactor. Environ. Technol. 1, 2016.

8. HERNÁNDEZ-RAMÍREZ D.A., HERRERA-LÓPEZ E.J., RIVERA A.L., DEL REAL-OLVERA J. Artificial neural network modeling of slaughterhouse wastewater removal of COD and TSS by electrocoagulation. Adv. Trends Soft Comput. Springer; 273, 2014.

9. KHOSA M.K., JAMAL M.A., ZIA K.M., SAIF M.J., BOKHARI T.H., RAZA M. Treatment of Cattle Slaughter House Wastewater by Electrocoagulation Method Using Aluminium Electrodes. Asian J. Chem. 26, 6335, 2014.

10. RODRÍGUEZ ABALDE Á. Anaerobic digestion of animal by-products: pre-treatments and co-digestion. 2013.

11. MESDAGHINIA A., AKHAVAN M.P., VAEZI F., NADDAFIK., MOOSAVIG. Waste sludge characteristics of a wastewater treatment plant compared with environmental standards. Iran. J. Public Health. 33, 5, 2004.

12. COSKUN T., DEBIK E., KABUK H.A., MANAV DEMIR N., BASTURK I., YILDIRIM B., TEMIZEL D., KUCUK S. Treatment of poultry slaughterhouse wastewater using a membrane process, water reuse, and economic analysis. Desalin. Water Treat. 57, 4944, 2016.

13. MORADI M., SAFARI Y., BIGLARI H., GHAYEBZADEH M., DARVISHMOTEVALLI M., FALLAH M., NESARI S., SHARAFI H. Multi-year assessment of drought changes in the Kermanshah city by standardized precipitation index. Int. J. Pharm. Technol. 8, 17975, 2016.

14. SAHU O., MAZUMDAR B., CHAUDHARI P. Treatment of wastewater by electrocoagulation: a review. Environ. Sci. Pollut. Res. 21, $2397,2014$.

15. STOŠIĆ M., ČUČAK D., KOVAČEVIĆ S., PEROVIĆ M., RADONIĆ J., SEKULIĆ M.T., MILORADOV M.V., RADNOVIĆ D. Meat industry wastewater: microbiological quality and antimicrobial susceptibility of E. coli and Salmonella sp. isolates, case study in Vojvodina, Serbia. Water Sci. Technol. 73, 2509, 2016.

16. RAHDAR S., AHAMADABADI M., KHAKSEFIDI R., SAEIDI M., NAROOIE M.R., SALIMI A., BIGLARI H., BANESHI M.M. Evaluation of phenol removal from aqueous solution by banana leaf ash. J. Glob. Pharma Technol. 9, 20, 2017.

17. BIGLARI H., SAEIDI M., ALIPOUR V., RAHDAR S., SOHRABI Y., KHAKSEFIDI R., NAROOIE M.R., ZAREI A., AHAMADABADI M. Review on hydrochemical and health effects of it in Sistan and Baluchistan groundwater's,Iran. Int. J. Pharm. Technol. 8, 17900, 2016.

18. PAN M., HENRY L.G., LIU R., HUANG X., ZHAN $X$. Nitrogen removal from slaughterhouse wastewater through partial nitrification followed by denitrification in intermittently aerated sequencing batch reactors at $11 \mathrm{C}$. Environ. Technol. 35, 470, 2014.

19. SAEIDI M., BIGLARI H., RAHDAR S., BANESHI M.M., AHAMADABADI M., NAROOIE M.R., SALIMI 
A., KHAKSEFIDI R. The adsorptive acid orange 7 using Kenya tea pulps ash from aqueous environments. J. Glob. Pharma Technol. 9, 13, 2017.

20. RAHDAR S., KHAKSEFIDI R., ALIPOUR V., SAEIDI M., NAROOIE M.R., SALIMI A., BIGLARI H., BANESHI M.M., AHAMADABADI M. Phenol adsorptive by cumin straw ash from aqueous environments. IIOAB J. 7, 536, 2016.

21. KHAKSEFIDI R., BIGLARI H., RAHDAR S., BANESHI M.M., AHAMADABADI M., NAROOIE M.R., SALIMI A., SAEIDI M., ALIPOUR V. The removal of phenol from aqueous solutions using modified saxaul ASH. Res. J. Appl. Sci. 11, 1404, 2016.

22. PÁRAMO-VARGAS J., GRANADOS S.G., MALDONADO-RUBIO M., PERALTA-HERNÁNDEZ J.M. Up to $95 \%$ reduction of chemical oxygen demand of slaughterhouse effluents using Fenton and photo-Fenton oxidation. Environ. Chem. Lett. 14, 149, 2016.

23. BIGLARI H., AFSHARNIA M., ALIPOUR V., KHOSRAVI R., SHARAFI K., MAHVI A.H. A review and investigation of the effect of nanophotocatalytic ozonation process for phenolic compound removal from real effluent of pulp and paper industry. Environ. Sci. Pollut. Res. Int. 24, 4105, 2017.

24. HAKIZIMANA J.N., GOURICH B., CHAFI M., STIRIBA Y., VIAL C., DROGUI P., NAJA J. Electrocoagulation process in water treatment: A review of electrocoagulation modeling approaches. Desalination. 404, 1, 2017.

25. BARRERA-DÍAZ C.E., FRONTANA-URIBE B.A., ROAMORALES G., BILYEU B.W. Reduction of pollutants and disinfection of industrial wastewater by an integrated system of copper electrocoagulation and electrochemically generated hydrogen peroxide. J. Environ. Sci. Heal. Part A. 50, 406, 2015.

26. WHEELDON L., WORTHINGTON T., LAMBERT P.A., HILTON A., LOWDEN C., ELLIOTT T.S. Antimicrobial efficacy of copper surfaces against spores and vegetative cells of Clostridium difficile: the germination theory. J. Antimicrob. Chemother. 62, 522, 2008.

27. FEDERATION W.E., ASSOCIATION A.P.H. Standard methods for the examination of water and wastewater. Am. Public Heal. Assoc. Washington, DC, USA. 2005.
28. AFSHARNIA M., KIANMEHR M., BIGLARI H., RAMEZANI M., RASOULI S. Coliform Removal from Municipal Waste Fresh Leachate Using Electrolysis Method with Iron and Copper Electrodes. Horizon. 21, 2015.

29. LAKSHMI P.M., SIVASHANMUGAM P. Treatment of oil tanning effluent by electrocoagulation: Influence of ultrasound and hybrid electrode on COD removal. Sep. Purif. Technol. 116, 378, 2013.

30. BARRERA-DÍAZ C., FRONTANA-URIBE B., BILYEU B. Removal of organic pollutants in industrial wastewater with an integrated system of copper electrocoagulation and electrogenerated $\mathrm{H}_{2} \mathrm{O}_{2}$. Chemosphere. 105, 160, 2014.

31. BAZRAFSHAN E., BIGLARI H., MAHVI A.H. Phenol removal by electrocoagulation process from aqueous solutions. Fresenius Environ. Bull. 21, 364, 2012.

32. MAHVI A.H., BAZRAFSHAN E., BIGLARI H. Humic acid removal from aqueous environments by electrocoagulation process using iron electrodes. E-Journal Chem. 9, 2453, 2012.

33. BANESHI M.M., NARAGHI B., RAHDAR S., BIGLARI H., SAEIDI M., AHAMADABADI M., NAROOIE M.R., SALIMI A., KHAKSEFIDI R., ALIPOUR V. Removal of remazol black B dye from aqueous solution by electrocoagulation equipped with iron and aluminium electrodes. IIOAB J. 7, 529, 2016.

34. KHOSRAVI R., HOSSINI H., HEIDARI M., FAZLZADEH M., BIGLARI H., TAGHIZADEH A., BARIKBIN B. Electrochemical decolorization of reactive dye from synthetic wastewater by mono-polar aluminum electrodes system. Int. J. Electrochem. Sci. 12, 4745, 2017.

35. RAHMANI A. Removal of water turbidity by the electrocoagulation method. J. Res. Health Sci. 8, 18, 2008.

36. REN Y.-Z., FRANKE M., ANSCHUETZ F., ONDRUSCHKA B., IGNASZAK A., BRAEUTIGAM P. Sonoelectrochemical degradation of triclosan in water. Ultrason. Sonochem. 21, 2020, 2014.

37. MASSOUDINEJAD M., YAZDANBAKHSH A., MOHAMADI B., HABIBE M. Possibility of making liquid Disinfectant from Electrolysis of $\mathrm{NaCl}$. Saf. Promot. Inj. Prev. 4, 69, 2016. 